OGNJEN Đ. MLADENOVIĆ

903.24”638”(497.11)

Belgrade, Serbia

069.51:903(497.113)

COBISS.SR-ID 254090252

RADOVAN V. SREMAC

Narodna biblioteka "Simeon Piščević"

Original research article

Zavičajna arheološka zbirka

Šid, Serbia

Received: April $13^{\text {th }} 2017$

VOJISLAV M. FILIPOVIĆ

Institute of Archaeology

Belgrade; Serbia

E-mail: vfilipov1@gmail.com

\title{
ASTRAGAL BELT FROM KABLAROVAC AND SEVERAL CHANCE FINDS FROM THE VICINITY OF ŠID
}

\begin{abstract}
This paper presents astragal belt which was discovered in 1989, in the course of archaeological excavations on Kablarovac site, not far from Gradina on Bosut river site, as well as several chance finds that are kept in "Zavičajna arheološka zbirka" in Šid. The main focus of this paper concerns typological and chronological analysis of astragal belt, based on belt buckle and the accompanying belt segments. Chance finds of astragal belt segments are analyzed as well.
\end{abstract}

KEYWORDS: ASTRAGAL BELT, BUCKLE, SEGMENTS OF ASTRAGAL BELTS, GRADINA ON BOSUT RIVER, SREM, LATE IRON AGE, TYPOLOGY, CHRONOLOGY

Multilayered archaeological site Gradina on Bosut River is situated on the left bank of the eponymous river, in the Vašica village, west Srem (Map 1/1). ${ }^{1}$ The site is comprised of fortified tell and wide suburbs outside of the defensive ditch, which stretched on both banks of the Bosut River. First mention of Gradina on Bosut River site is related to the late XIX century, when Antun Bogetić, a monk from Sotin, collected first archaeological artifacts, and on that occasion gave a detailed plan of the site. In the following 80 years, Gradina on Bosut River site practically does not exist in archaeological literature, until the build-

1 The article results from the project: Archaeology of Serbia: cultural identity, factors of integration, technological processes and the role of the central Balkans in European prehistory (no. OI177020), visualization (no 47018), funded by The M inistry of E ducation, Science and Technological Development of the Republic of Serbia. ing of the bridge on Bosut River in 1960, which to a great extent damaged the site, draw attention of the archaeologists. Not long after, first protective excavations were conducted, in the period from 1964 to 1965. A decade later, in 1975, systematic archaeological excavations begin, which lasted until 1989 without interruption (Medović, Medović 2011: 5-7), while last protective archaeological excavations took place in 2013. All of the aforementioned excavations provided detailed stratigraphic situation, so today we can speak about cultural layers on Gradina starting from the Late Neolithic to the very end of the Middle Age. ${ }^{2}$

The excavations in 1989 were focused on Kablarovac area (Map 1/2), some 800 meters eastern

2 The results of the excavations of the Gradina on Bosut River site are published on several occasions: Popović 1981; Поповић и Радојчић 1996; Ророvić 2003; Меdović i Medović 2011; Сремац 2014; idem 2016. 


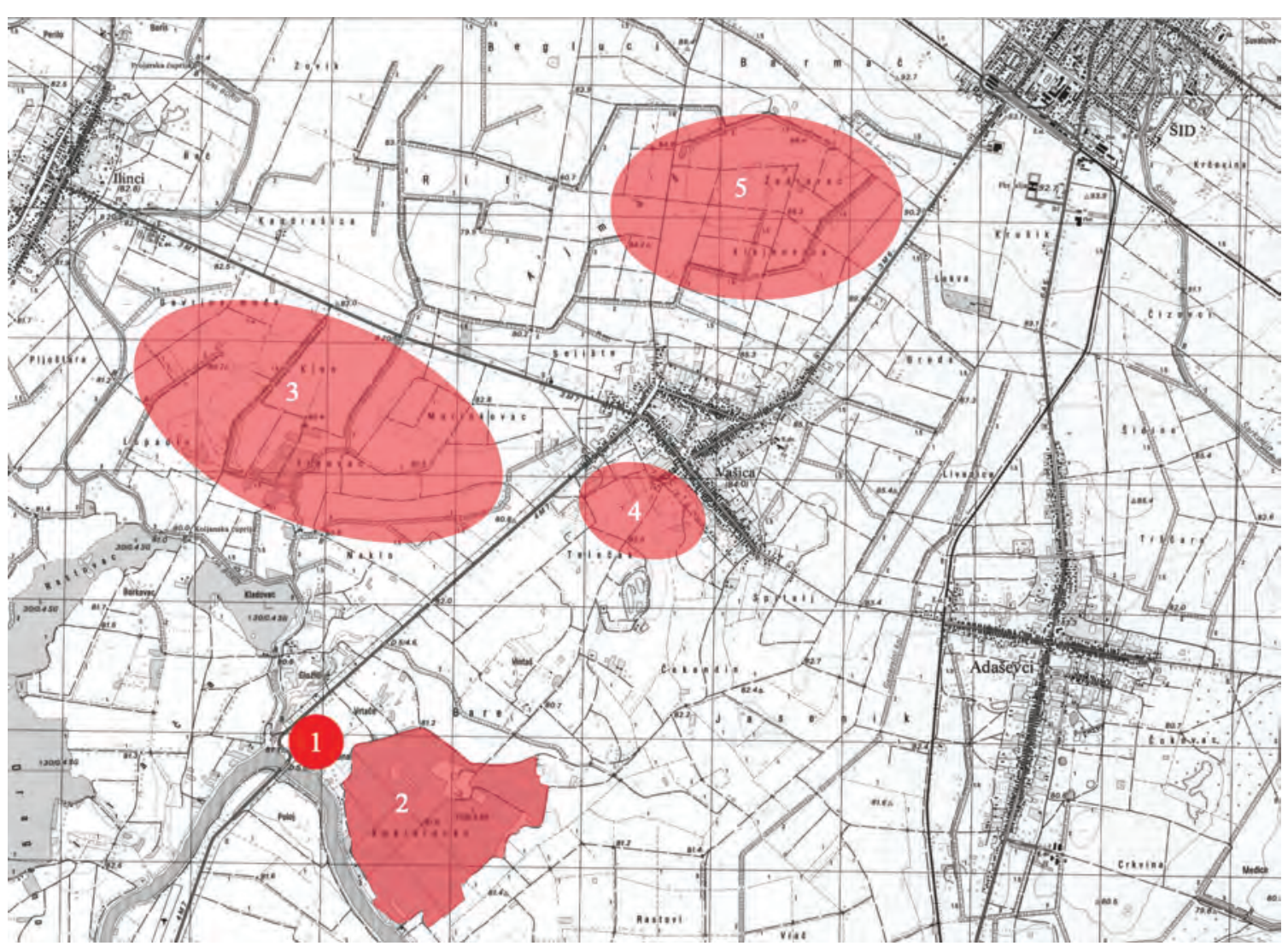

Map 1 1. Gradina on Bosut River; 2. Kablarovac; 3-5. Locations from which chace finds of belt segments originate (Gradina - Ilinci - Vašica area).

from Gradina itself, where a periphery of a Late Iron Age necropolis was explored. On that occasion, parts of at least three astragal belts were recovered, ${ }^{3}$ of which two have been previously published (Popović 2003: 311 and further; Арсенијевић 2013: 56-57), while parts of the third belt were handed over to "Zavičajna arheološka zbirka" in Šid after conservation in Musem of Vojvodina in Novi Sad, ${ }^{4}$ and until now remained unpublished. ${ }^{5}$ Aside from the excavated part of the necropolis, pottery workshops registered at Kalodžinci site not far from Gradina, as well as series of chance finds (pottery, fibulae, coins) from unexcavated sites in Ilinci (Klenovac, Džombulja, Umka) and Vašica

3 For detailed information on astragal belts refer to: Božić 1981; Vasić 1989; Jovanović 1998; Filipović, Mladenović 2017.

4 Parts of astragal belt came to "Zavičajna arheološka zbirka" in Šid with no supporting documentation.

5 An illustration of belt was provided in the popular science publication Radosavljević, Sremac 2013: sl. 18.
(Kapela, Popine krčevine, Galića šljivik, Vrtače) villages can be associated to the Late Iron Age period (Map 1/3-5). Observed in a wider geographical context, the whole Gradina - Ilinci - Vašica area is rich with Late Iron Age archaeological finds.

The main focus of this paper will be on mentioned unpublished astragal belt, its typological and chronological analysis, as well as the analysis of several chance finds that are kept in "Zavičajna arheološka zbirka" in Šid, and originate from the aforementioned sites and routes. The goal of this paper is to associate this unpublished finds with general geographical, chronological and typological classification of astragal belts, ${ }^{6}$ while on the other hand the paper will not deal with any social and ethnic issues associated with this kind of objects.

6 Typological analysis of belt buckles will be based on Арсенијевић 2013, and the typology of astragal belts segments will be based on Filipović, Mladenović 2017. 


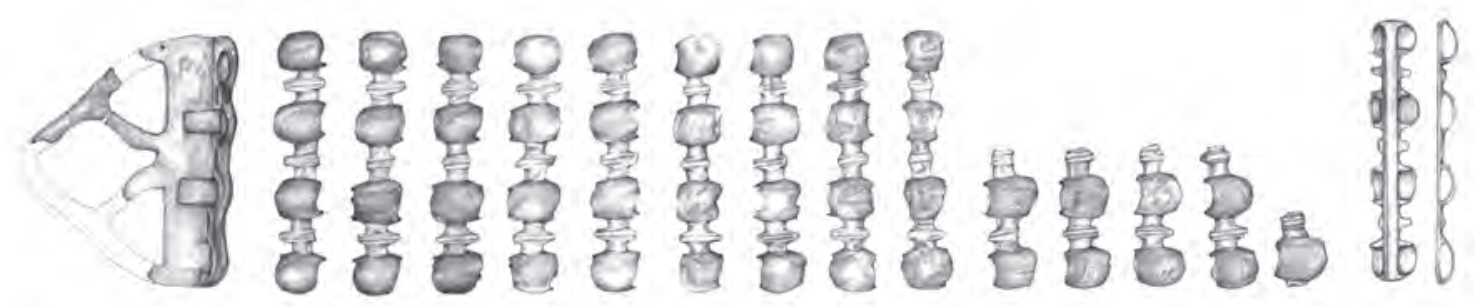

Fig. 1 Astragal belt from Kablarovac.

On astragal belt from Kablarovac (Fig. 1) nine completely and five fragmented bronze segments are preserved, as well as one fragmented belt buckle. Bronze belt buckle from Kablarovac is comprised of rectangular plate with loops for attaching onto belt preserved on the back side. The belt was probably made out of some organic material. Two prongs which connected at some point emerge from the plate, forming a triangular field. Inside this triangular field, one larger, rhomboid perforation, and two smaller, triangular perforations are observed. The only similar example of belt buckle is found in Donja Dolina, as chance find from the Iron Age necropolis (Maric 1964: T. XIV/25). However, this example is decorated with punctuated ornament with double concentric circles and smaller punction in the middle, which are equally arranged on the entire surface of the buckle, while our example lacks any decoration. S. Arsenijević classifies this buckle into her type VII - donjodolinski (triangular belt buckles of perforated type), and dates it to the III century В.С. (Арсенијевић 2013: 59, tabela 12). From Kablarovac also comes two mentioned belt buckles (Popović 2003: 319, T. 4/14-15), but these are younger examples, the so-called elongated bellshape modeled belts (Dizdar, Tonc in print).

Completely preserved segments of this belt are comprised of four calottes, three horizontal bars, and four loops for sewing onto belt (Fig. 2). Horizontal bars on all segments are decorated with two horizontal incisions. Four segments have two calottes, and two horizontal bars preserved, while one segment has only one calotte and one hori- zontal bar preserved. On fragmented segments the number of loops for sewing onto belt corresponds to the number of preserved calottes. Based on the round shape of calottes, clearly defined transition from calotte to horizontal bar, as well as characteristic decoration comprised of incised horizontal lines, all segments of this belt can be classified into the Osijek variant of Srem type (Filipović, Mladenović 2017: 159-163). This variant of segments is most abundant on the territory of present day Srem, while it's distribution is connected to a wide territory between Balaton Lake in Hungary and Mačva in Serbia, and further to the east towards Great Morava and Dunav rivers confluence, but similar examples are known from the territories of Slovakia and Romania (Pieta 2014: 149-152, Obr. 19/1; Rustoiu 2011: 166, Fig. 4/4), and further to the south, in the South Morava River Basin (Булатовић 2007: 167-169, Т. XLII/3).

Segments of astragal belt from Kablarovac are similar to one of the previously published belt from this site (Popović 2003: 319, T. 4/13), as well as to examples from Donja Dolina, Vučedol near Vukovar, Donji grad in Osijek, Nikinci, Čair near

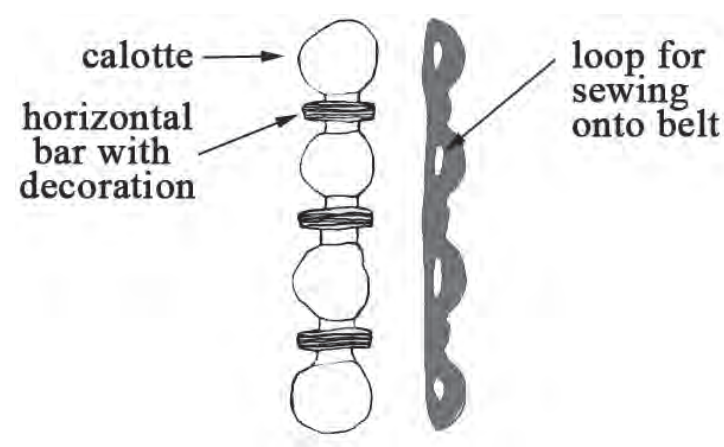

Fig. 2 Constructive elements of an astragal belt segment. 
Stari Kostolac (Jovanović 1998: T. II/10, T. V/10, T. IV/7-8, T.V/4, T. IX/1-2), Batina (Maráz 1983: T. III/ 1), and example from Paulje necropolis in Brezjak (Булатовић, Филиповић и Глигорић 2017: 132, kat. 51, T. XX/51). Relatively large number of examples similar to ours are also found on sites Beremend, Lengyel, Gerenyápuszta, Regöly, Kosd (Jovanović 1998: T. X/40-41, 4344, T. XI/3) and Mözs-Tolna (Gaál 2001: 10. tábla, 11. tábla) in Hungary.

\section{$* * *$}

"Zavičajna arheološka zbirka" in Šid also keeps 23 segments of astragal belts, in different degree of preservation. Only two segments are completely preserved, one segment has four calottes preserved, one segment has three calottes preserved, 15 segments have two calottes preserved, and four segments have only one calotte preserved. All this segments are chance finds recovered from aforementioned Gradina - Ilinci Vašica area.

1. Segment of astragal belt that consists of four calottes, and three horizontal bars. Horizontal bars are decorated with horizontal lines. Bronze, casting; length 5,6 cm, width $1,2 \mathrm{~cm}$ (T. I/1).

2. Segment of astragal belt that consists of four calottes, and three horizontal bars. Horizontal bars are decorated with horizontal lines. Bronze, casting; length $6,3 \mathrm{~cm}$, width $1,5 \mathrm{~cm}$ (T. I/2).

3. Preserved fragment of astragal belt segment with three calottes, and two horizontal bars. Horizontal bars are decorated with horizontal lines. Bronze, casting; length 4,6 cm, width $1 \mathrm{~cm}$ (T. I/3).

4. Preserved fragment of astragal belt segment with two calottes, and two horizontal bars. Horizontal bars are decorated with horizontal lines. Bronze, casting; length $3,5 \mathrm{~cm}$, width 1,4 cm (T. $\mathrm{I} / 4)$.

5. Refer to Cat. No. 4. Bronze, casting; length 3,3 cm, width $1,1 \mathrm{~cm}$ (T. I/5).

6. Refer to Cat. No. 4. Bronze, casting; length 3,6 cm, width 1,2 cm (T. I/6).

7. Refer to Cat. No. 4. Bronze, casting; length
3,2 cm, width 1,2 cm (T. I/7).

8. Preserved fragment of astragal belt segment with two calottes, and one horizontal bar. Horizontal bar is decorated with horizontal lines. Bronze, casting; length 2,6 cm, width $1 \mathrm{~cm}$ (T. I/8).

9. Refer to Cat. No. 8. Bronze, casting; length 2,7 cm, width 0,8 cm (T. I/9).

10. Refer to Cat. No. 8. Bronze, casting; length $3,1 \mathrm{~cm}$, width $0,8 \mathrm{~cm}(\mathrm{~T} . \mathrm{I} / 10)$.

11. Refer to Cat. No. 8. Bronze, casting; length 2,4 cm, width $1,2 \mathrm{~cm}$ (T. I/11).

12. Preserved fragment of astragal belt segment with two calottes, and two horizontal bars. Bronze, casting; length $3,5 \mathrm{~cm}$, width $1,2 \mathrm{~cm}$ (T. I/12).

13. Preserved fragment of astragal belt segment with two calottes, and one horizontal bar. Bronze, casting; length $3,3 \mathrm{~cm}$, width $1,2 \mathrm{~cm}$ (T. I/13).

14. Refer to Cat. No. 13. Bronze, casting; length $2,7 \mathrm{~cm}$, width $1,2 \mathrm{~cm}$ (T. I/14).

15. Refer to Cat. No. 13. Bronze, casting; length 2,9 cm, width $1 \mathrm{~cm}$ (T. I/15).

16. Preserved fragment of astragal belt segment with one calotte, and one horizontal bar. Horizontal bar is decorated with horizontal lines. Bronze, casting; length $1,9 \mathrm{~cm}$, width $1,4 \mathrm{~cm}$ (T. I/16).

17. Refer to Cat. No. 15. Bronze, casting; length $1,4 \mathrm{~cm}$, width $0,7 \mathrm{~cm}$ (T. I/17).

18. Preserved fragment of astragal belt segment with one calotte. Bronze, casting; length 1,3 $\mathrm{cm}$, width $1,1 \mathrm{~cm}$ (T. I/18).

19. Preserved fragment of astragal belt segment with three calottes, and two horizontal bars. Horizontal bars are decorated with horizontal lines. Bronze, casting; length $3,5 \mathrm{~cm}$, width 1,4 cm (T. I/19).

20. Preserved fragment of astragal belt segment with two calottes, and one horizontal bar. Horizontal bar is decorated with horizontal lines. Bronze, casting; length $2,9 \mathrm{~cm}$, width $1,1 \mathrm{~cm}$ (T. I/20).

21. Preserved fragment of astragal belt segment with two calottes, and one horizontal bar. Bronze, casting; length $2,7 \mathrm{~cm}$, width $1,2 \mathrm{~cm}$ (T. I/21).

22. Preserved fragment of astragal belt segment with one calotte, and one horizontal bar. Horizon- 
tal bar is decorated with horizontal lines. Bronze, casting; length $1,6 \mathrm{~cm}$, width $0,9 \mathrm{~cm}$ (T. I/22).

23. Preserved fragment of astragal belt segment with four calottes, and four horizontal bars. Horizontal bars are decorated with oblique rib. Bronze, casting; length $5 \mathrm{~cm}$, width $1 \mathrm{~cm}$ (T. I/23).

Concerning the typology, all presented segments can be classified into the Srem (Osijek and Belgrade variants) and Dunaszekcső types. Most examples (18) belong to the Osijek variant of Srem type (Filipović, Mladenović 2017: 159-163). These are examples with round calottes, clearly defined transition from calotte to horizontal bar, and for this type characteristic decoration consisting of horizontal incisions (T. I/1-17). The decoration differs from example to example, meaning that the number of incisions is different, so we find examples with one, two, or three incisions. Also, due to the preservation degree of some segments, incisions are not clearly visible, but based on the other constructive elements one can assume that they belong to this type and variant. Similar to the examples from Kablarovac, with which they display certain similarities, we find close analogies for this segments on various sites and finds from the territory of Srem (Jovanović 1998: T. V/3-5, T. $\mathrm{X} / 17,20,22$, 34; Filipović i Mladenović 2017: T. 1/2-20, 22-26, 28-30, 36-37, 42-53, 57-58, T.2/67) and Hungary (Jovanović 1998: T. X/40-41, 43-44, T. XI/3; Gaál 2001: 10. tábla, 11. tábla; Almássy 2014: 241, fig. 3/1), and on sites Donji grad in Osijek (Jovanović 1998: T. IV/4-7), and Vukovar (Jovanović 1998: T. V/10).

Examples with calottes whose shape is more rectangular with rounded edges, and shorter and rounder horizontal bars decorated with wider oblique incisions are classified into the Belgrade variant (Srem type) (T. I/18-21). As with the segments of previous variant, these segments also display certain differences concerning the number of lines that comprise the decoration of horizontal bar. We find examples similar to ours first of all in the territory of Srem, in Laćarak (Filipović i Mladenović 2017: T. 1/31-32, 34-35, 38-39, 51,
54), Krušedol, Prhovo, Novi Banovci and Surčin (Jovanović 1998: T. VI/7, T. VI/5-6, T. VII/9-12). ${ }^{7}$

Only one example is classified into the Dunaszekcsö type (T. I/22). The transition from calotte to horizontal bar is not so distinct, and horizontal bars are decorated with ribs, and maybe even oblique incisions, although the state of preservation of the segment surface is not suitable for more detailed analysis. We find examples similar to ours also in the territory of Srem (Sremska Mitrovica, Novi Banovci) (Jovanović 1998: T. VII/4, 20), in Svrljig (Filipović i Mladenović 2017: T. 2/59-60), and Blato site near Vinkovci (Dizdar 2015, fig. 11: 4-5). Since this type of astragal belt segments has very wide territorial distribution, similar examples are also found in the teritories of Hungary, Romania, and Slovakia (Jovanović 1998: T. X/42, T. XI/4-8; Rustiou 1996: fig. 73; idem 2012: pl. 3/5-6; Březinová, Samuel 2007: obr. 45).

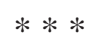

In order to determine as precise chronology as possible for astragal belt from Kablarovac, we must approach this issue from two different perspectives. We must first deal with the chronology of the Kablarovac belt buckle, which is a problem by itself, bearing in mind that not a single find of this type of belt buckle comes from enclosed context. As previously mentioned, the most similar example to ours comes from Donja Dolina site, and even as it was discovered in the course of the necropolis excavation, it represents a chance find. Z. Marić (Marić 1964: 40-43) dates the finds from the necropolis to Donjodolinska II phase, i.e. period from 500 to 360 years BC. Among chance finds from necropolis we find chronologically very diverse material, like different types of double pins (Marić 1964: T. XIII/3, 4), which R. Vasić dates into a very long period from the VII to II century BC (Vasić 2003: 118-120, 123-126), ${ }^{8}$ then sev-

7 Isolated exampes typologicaly simillar to ours are discovered at Căpâlna site in Romania (Glodariu, Moga 1989: T. XII: 10,12).

8 For the territory of western Bosnia and Herzegovina, dating is closer to the V and IV century BC (Vasić 2003: 126). 
eral examples of bronze buttons (Marić 1964: T. XIV/15, 20), which can based on analogies be dated to the VII and VI century BC (Videski, Temov 2005: 17-18, kat. 71-81), but also three-looped and one-looped astragal belt buckles (Marić 1964: T. $\mathrm{XIV} / 24,28,29)$, dated to the III century BC by S. Arsenijević. The apperance of such a chronologicaly diverse finds does not suprise, having in mind that burials are continuously practiced at Donja Dolina from the beginning of the VII century BC, to the final decades of the II century BC (Marić 1964: 32-49). On the other hand, no finds from enclosed contexts originate from Kablarovac, so in therms of chronology we must point out finds of a copmosite bell-shaped belt buckle of astragal belt with button-like decoration (Popović 2003: T. 4/14), which S. Arsenijević dates to the end of the III and II century BC (Арсенијевић 2013: 56-57), and finds of Laminci type belt buckles (Popović 2003: T. 5/11, 12) dated to the III and I century ВC (Арсенијевић 2013: 74-75), as well as one Middle La Tène fibula which P. Popović based on similar examples from Baraće site in Đerdap and Čubursko brdo site near Negotin dates to the end of the III and the beginning of II century BC (Popović 2003: 313, T. 4/2).

The chronology of astragal belt segments that make up astragal belt from Kablarovac, can be very useful in determining the chronology of the belt itself. As previously noted, all segments of this belt are classified into the Srem type, Osijek variant, for which we find numerous analogies on the territories of Srem and Hungary (Filipović, Mladenović 2017:161, karta 2). Based on grave finds from Novi Jankovci, and Vinkovci (Silos site), as well as from sites Beremend, Szárazd-Gerenyápuszta, Mözs-Tolna, and Kosd in Hungary, M. Dizdar and A. Tonc date the upper chronological border for the appearance of this type of astragal belt segments to the VI century BC (Dizdar, Tonc in print), bearing in mind that based on similar finds from Grave 1 of Mound XV at the Paulje necropolis, where they appear together with bronze bracelets with crossed and slightly thinned ends, this chronological border could be placed even to the end of the VII century ВC (Булатовић, Филиповић, Глигорић 2017: 132-134, кат. бр. 51-58). The lower chronological border is defined solely by Grave 26 from Osijek, which is dated to the end of the III and the beginning of II century BC (Dizdar, Tonc in print).

Considering all of the aforementioned, dating of astragal belt from Kablarovac represents an undisclosed issue for now, having in mind that the finds discovered at sites where this belt buckle type appears (Donja Dolina and Kablarovac) are dated into a very long period from the end of the VII to I century BC. Based on the type/variant to which the segments of the belt are classified, the lower chronological border could be dated to the end of the III and the beginning of II century BC, which is also the lower chronological border for appearance of this type of astragal belt segments. Precise defining of the upper chronological border is significantly uncertain, primarily to the fact that this type of belt buckle appears with chronologically diverse finds. Based on those finds and the chronology of segments, upper chronological border could be dated to the VI century BC, although based on the constructive elements of the buckle, and the fact that it could represent a certain phase of evolutional development from the three-looped to bell-like belt buckles, our opinion is that the upper chronological border should be dated to the IV century BC. Such a wide chronological span in dating could be more precisely determined by the fact that the finds from Kablarovac are dated to a period from the III to I century BC (Popović 2003: 312-313). Considering this, dating of the astragal belt from Kablarovac could rather be placed into the III or the very beginning of II century BC, ${ }^{9}$ but earlier dating should not be excluded.

Speaking of chance finds of astragal belt segments from Gradina - Ilinci - Vašica area, they can only be dated based on the chronology of the belonging type/variant. Examples classified into

9 S. Arsenijević also dates belt buckle from Donja Dolina into the III century BC (Арсенијевић 2013: 56-57, tab. 12). 


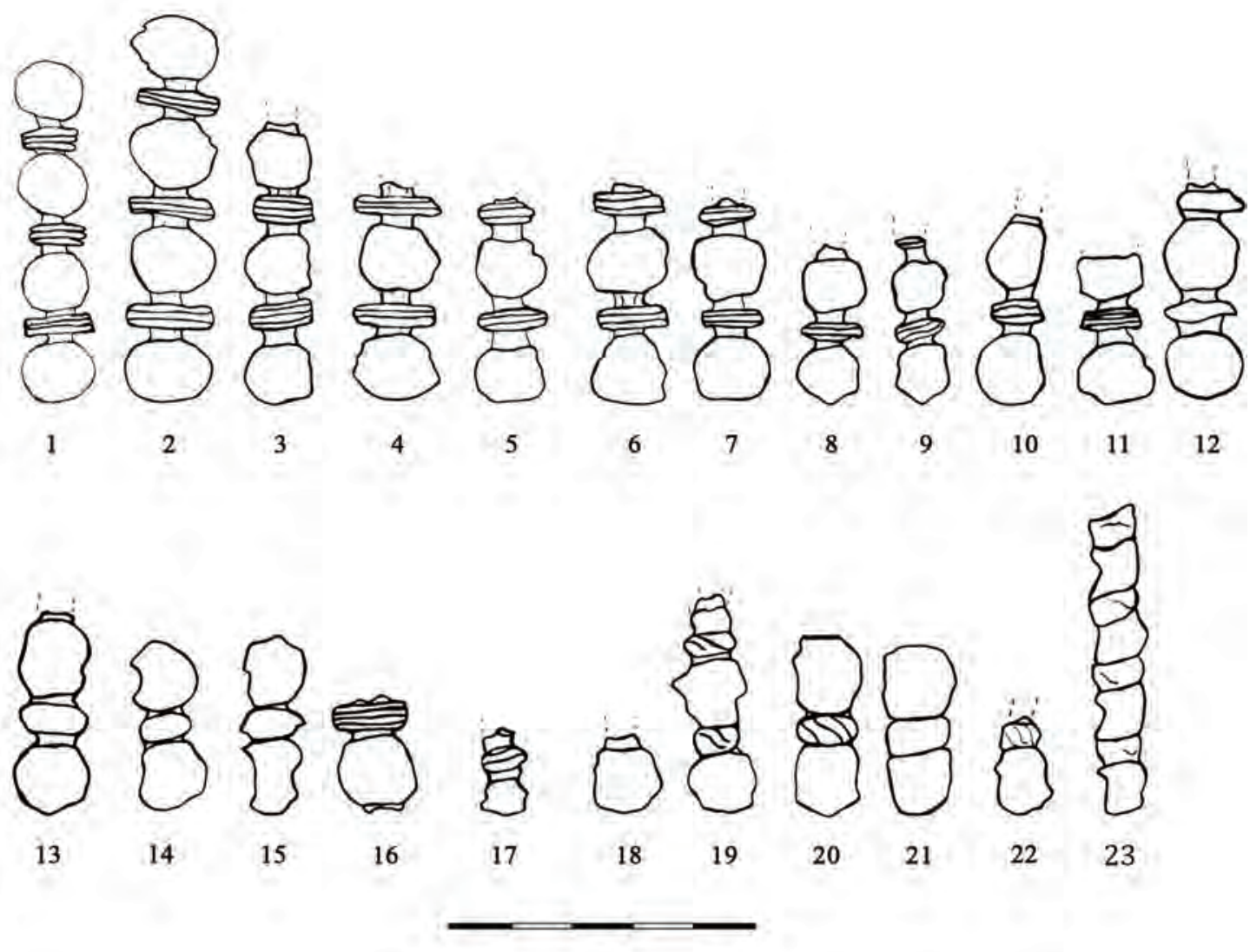

T. I Segments of astrgal belts disvovered in Gradina - Ilinci - Vašica area.

the Osijek variant (Srem type) (T. I/1-17) are dated to the period from the VI to III or the beggining of II century BC, examples classified into the Belgrade variant (Srem type) (T. I/18-21) into the II and I century BC, while example classified into the Dunaszekcső type (T. I/22) is dated into the period from the mid II to the end of I century BC (Filipović, Mladenović 2017). ${ }^{10}$

$$
* * *
$$

Astragal belt from Kablarovac to a certain extent complements our previous knowledge of appearance of various types of astragal belts, which depends both on belt buckle type, and also on the type of accompanying belt segments. It also fits into previously suggested concept of the center of production and distribution of this type

10 Such dating of the Dunaszekcső type segments has to be taken with a certain caution, since the number of segments coming from enclosed contexts is low. of segments in the territory of Srem (Filipović, Mladenović 2017). The type of belt buckle can be pointed out as a certain specifikum od this belt, as it represents a lone find in the territory of Srem, while similar example was found only in Donja Dolina. Such observation could in a certain way point out to distribution and use of this type of belt buckles on a wider territory od Sava river region. Likewise, future finds could provide answer to the issue of precise chronological positioning of this type of belt buckles, and at the same time issues of the initial territory, from which the distribution could be followed. On the other hand this could contribute to solving certain issues concerning the reasons for switching the place of production for some of the astragal belt segment types. 


\section{BIBLIOGRAPHY}

\section{Almássy, K. 2014}

Contacts between the Upper Tisza Region and the Balkans in the 3rd century BC, The Clash of Cultures? The Celts and the Macedonian World, M. Guštin and W. David (eds.), Manching: 239-246. (in print).

\section{Арсенијевић, С. 2013}

Појасне копче млађег гвозденог доба на тлу западног и централног Балкана, Бањалука: ЈУ Музеј Републике Српске.

\section{Březinová, G. and Samuel, M. 2007}

Prehl'ad osídlenia, „Tak čo, našli ste niečo? “, G.

Březinová and M. Samuel (eds.), Nitra: Archeologický ústav SAV: 15-69.

Božič, D. 1981

Kasnolatenski astragalni pojasevi tipa Beograd, Starinar XXXII: 47-56.

\section{Булатовић, А. 2007}

Врање - културна стратиграфија праисторијских локалитета у Врањској регији, Београд - Врање: Археолошки инситут - Народни музеј Врање.

Булатовић, А., Филиповић, В. и Глигорић, Р. 2017

Лозница, Београд - Лозница: Археолошки институт - Музеј Јадра.

\section{Dizdar, M. 2015}

Late La Tène Settlements in the Vinkovci Region (Eastern Slavonia, Croatia): Centres of Trade and Exchange, Boii - Taurisci. Karwowski M. and Ramsl, P.C (eds.), April 14-15 2012 Oberleis-Klement, Austria. Österreichische Akademie der Wissenschaften: $31-48$.

Dizdar, M., Tonc, A. (in print)

Not just a belt: Late Iron Age female costume in the south-east Carpathian Basin, Proceedings of the Conference Craft and Production in the European Iron Age, September 25-27 2015, Cambridge.

Filipović, V. i Mladenović, O. 2017

Prilog proučavanju članaka astragalnih pojaseva sa teritorije centralne i jugoistočne Evrope, Prilozi Instituta za arheologiju u Zagrebu 34: 144-183.

Gaál, A. 2001

Késő vaskori sír az S-9-es út területéről, Tolna megye évszázadai a régészet tükrében, Szekszárd: Wosinsky Mór Megyei Múzeum: 27-30.

Glodariu, I. and Moga, V. 1989

Cetatea dacică de la Căpâlna, Alba Iulia: Ed. Altip.

Jovanović, M. 1998

Astragalni pojasevi na području centralnog Balkana i jugoistočne Evrope, Rad Muzeja Vojvodine 40: 39-94.

\section{Maráz, B. 1983}

La Tene-kori leletek Jugoszláviából és Romániából magyarországi múzeumokban, JPMÉ 27: 107-116.

\section{Marić, Z. 1964}

Donja Dolina, Glasnik Zemaljskog muzeja n.s XIX: 5-128.

\section{Medović, P. i Medović, I. 2010}

Gradina na Bosutu. Naselje starijeg gvozdenog doba, Novi Sad: Pokrajinski zavod za zaštitu spomenika kulture AP Vojvodine.

\section{Pieta, K. 2014}

Hradiská vo Folkušovej - Necpaloch a Blatnici: juhovýchodné prvky v púchovskej kultúre, Slovenská archeológia LXII, č. 1: 125-165.

\section{Popović, D. 1981}

Keramika starijeg gvozdenog doba u Sremu, Beo- 
grad - Sremska Mitrovica: Savez arheoloških društava Jugoslavije - Zavod za zaštitu spomenika kulture.

\section{Поповић, Д. и Радојчић, Н. 1996}

Градина на Босуту (каталог изложбе), Галерија слика 'Сава Шумановић”.

\section{Popović, P. 2003}

Gradina na Bosutu kod Vašice, Opuscula archaeologica 27: 311-320.

Радосављевић, А. и Сремац, Р. 2013

Водич за мале праисторичаре, Шид: Галерија слика “'Сава Шумановић”.

\section{Rustoiu, A. 1996}

Metalurgia Bronzului La Daci (sec. II 1. Chr. sec. I d. Chr.) Tehnici, ateliere Si produse de bronz, Bucureşti: Institutul Roman de Tracologie.

\section{Rustoiu, A. 2011}

The Celts from Transylvania and the eastern Banat and their southern neighbours. Cultural exchanges and individual mobility, The Eastern Celts. M. Guštin and M. Jevtić (eds.), Beograd-Koper: Filozofski fakultetet, Univerzitet u Beogradu Univerza na Primorskem, Znanstveno-raziskovalno središče, Založba Annales: 163-170.

\section{Rustoiu, A. 2012}

The Celts and Indigenous Populations from the Southern Carpathian Basin. Intercommunity Communication Strategies, Iron Age Rites and Rituals in the Carpathian Basin. S Berecki (ed.), Proceedings of the International colloquium from Târgu Mureș, 7-9 October 2011, Târgu Mureș: Editura MEGA: 357-390.

\section{Сремац, Р. 2014}

Градина на Босуту (каталог сталне поставке), Шид: Народна библиотека 'Симеон Пишчевић”.

\section{Сремац, Р. 2016}

Заштитна археолошка ископавања локалитета градина на Босуту, Грађа за проучавање споменика културе Војводине XXIX: 47-56.

\section{Vasić, R. 1989}

Jedan prilog proučavanju sremske grupe, Godišnjak CBI ANUBiH XXVII: 103-113.

\section{Vasić, R. 1999}

Die Fibeln im Zentralbalkan (Vojvodina, Serbienm Kosovo und Makedonien), PBF: Abt. XIV; Bd. 12. Stuttgart: Franz Steiner Verlag.

\section{Vasić, R. 2003}

Die Nadeln im Zentralbalkan (Vojvodina, Serbienm Kosovo und Makedonien), PBF: Abt. XIII;

Bd. 11. Mainz: Franz Steiner Verlag.

Videski, Z. and Temov, S. 2005

Makedonske bronce, Zagreb: Arheološki muzej u Zagrebu - Muzej Makedonije. 


\section{REZIME}

ASTRAGALNI POJAS IZ KABLAROVCA I NEKOLIKO SLUČAJNIH NALAZA IZ OKOLINE S̆IDA

\section{KLJUČNE REČI: ASTRAGALNI POJAS, KOPČA, ČLANCI ASTRAGALNIH POJASEVA, GRADINA NA BOSUTU, SREM, MLAĐE GVO- ZDENO DOBA, TIPOLOGIJA, HRONOLOGIJA.}

U radu se prikazuje astragalni pojas koji je otkriven 1989. godine prilikom arheoloških istraživanja lokaliteta Kablarovac nedaleko od Gradine na Bosutu, kao i nekoliko slučajnih nalaza članaka astragalnih pojaseva iz okoline Šida, koji se danas čuvaju u Zavičajnoj arheološkoj zbirci. $\mathrm{Na}$ astragalnom pojasu iz Kablarovca sačuvano je devet kompletnih i pet fragmentovanih bronzanih članaka, kao i jedna fragmentovana pojasna kopča, koja se sastoji od pravougaone pločice na čijoj su zadnjoj strani očuvani otvori za pričvrščivanje na pojas. Sa pločice polaze dva kraka, koja su se spajala, i time formirala pravilno trougaono polje. Unutar njega, nalazi se jedna veća romboidna perforacija, kao i dve manje, trougaone perforacije. Jedini primerak sličan kopči sa Kablarovca nalazimo u Donjoj Dolini, kao slučajan nalaz sa nekropole starijeg gvozdenog doba. Kompletno sačuvani članci ovog pojasa se sastoje od po četiri kalote, tri poprečne prečage, $i$ četiri rupe za prišivanje pojasa. Poprečne prečage su na svim člancima ukrašene sa po dva horizontalna ureza. Četiri članka imaju očuvane po dve kalote, $i$ dve poprečne prečage, dok je na jednom članku sačuvana samo jedna kalota $i$ jedna poprečna prečaga. Kod fragmentovanih članaka broj rupa za prišivanje pojasa odgovara broju kalota, a poprečne prečage takođe su ukrašene sa po dva horizontalna ureza. Na osnovu kružnog oblika kalota, te jasno izdvojenog prelaza iz kalote u poprečnu prečagu, ali i karakterističnog ukrasa koji je sačinjen od urezanih horizontalnih linija, svi članci ovog pojasa mogu su opredeliti u tip Srem, varijantu Osijek. Ova varijanta članaka najviše je zastupljena na teritoriji današnjeg Srema, dok joj se distribucija vezuje za prostanu teritoriju između jezera Balaton u Mađarskoj i Mačve u Srbiji, te dalje na istok prema ušću Velike Morave u Dunav, ali su slični primerci poznati i sa teritorije Slovačke i Rumunije i prema jugu, u basenu Južne Morave. Članci pojasa iz Kablarovca slični su jednom od ranije publikovanih primeraka sa istog lokaliteta, te primercima iz Donje Doline, Vučedola kod Vukovara, Donjeg grada u Osijeku, Nikinaca, Čaira kod Starog Kostolca, Batine, kao i primerku sa nekropole Paulje u Brezjaku. Srazmerno veći broj primeraka sličnih našem nalazimo i na lokalitetima Beremend, Lengyel, Gerenyápuszta, Regöly, Kosd i Mözs-Tolna na teritoriji Mađarske. Na osnovu pokretnih nalaza iz grobova iz Novih Jankovca i Vinkovaca (lokalitet Silos), te Beremenda, Szárazd-Gerenyápuszte, Mözs-Tolne i Kosda u Mađarskoj, M. Dizdar i A. Tonc postavljaju gornju hronološku granicu pojave ovog tipa članaka u drugu polovinu VI veka pre n.e., s tim da bi se na osnovu sličnih nalaza iz groba 1 humke XV sa Paulja, gde se javljaju i bronzane narukvice sa prebačenim i blago stanjenim krajevima, ova granica mogla pomeriti čak i u kraj VII veka pre n.e. Donja hronološka granica za ovaj tip članaka definisana je jedino grobom 26 iz Osijeka, koji je opredeljen u sam kraj III ili početak II veka pre n.e.

U zavičajnoj arheološkoj zbirci u Šidu čuva se i 22 članka astragalnih pojaseva, različitog stepena očuvanosti. Samo je jedan članak u potpunosti očuvan, po jedan članak ima očuvane četiri, odnosno tri kalote, 15 članaka ima očuvane dve kalote i na četiri članka je očuvana samo jedna kalota. Svi oni su slučajni nalazi koji su otkriveni na pomenutom potesu Gradina - Ilinci - Vašica. Tipološki posmatrano, svi prikazani članci mogu se opredeliti u tipove Srem (varijante Osijek i Beograd) i Dunaszekcső. Primerke koji pripadaju varijanti Osijek (tip Srem) trebalo bi opredelili u period od VI do III ili početka II veka pre n.e., a primerke varijante Beograd (tip Srem) u II i I vek pre n.e., dok bi primerak tipa Dunaszekcső pripadao periodu od sredine II do kraja I veka pre n.e. 